\title{
Invasive Breast Cancer: Recognition of Molecular Subtypes
}

\author{
Johanna D. Strehl $\mathrm{a}^{\mathrm{a}} \quad$ David L. Wachter ${ }^{\mathrm{a}^{*}} \quad$ Peter A. Fasching $^{\mathrm{b}}$ \\ Matthias W. Beckmann ${ }^{b}$ Arndt Hartmann ${ }^{a}$ \\ anstitute for Pathology,

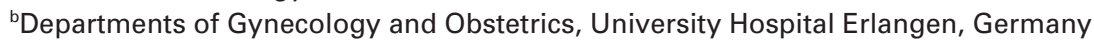

\section{Keywords}

Invasive breast cancer - Molecular subtypes .

Luminal type $\cdot$ Basal type $\cdot$ HER2

\section{Summary}

Molecular profiling has fundamentally changed our understanding of breast cancer in the last 10 years, by creating a new taxonomy of breast cancers based on the expression patterns of so-called 'intrinsic genes'. Hierarchical clustering analyses performed on microarray-based gene expression profiles of breast cancers defined distinct breast cancer subgroups (luminal type $A / B$, HER2-enriched type, basal-like type). Since the initial landmark study by Perou et al., the concept of intrinsic breast cancer subtypes has been corroborated and expanded by several independent research groups. Further studies revealed individual properties of the intrinsic subgroups regarding the clinical course and the responsiveness to chemotherapy. The new gene expression profile-based taxonomy of breast cancer has been enthusiastically embraced by the scientific community and hailed as a major breakthrough on the way to individually tailored therapies. However, validation of the gene signatures in prospective studies is necessary before accepting these new technologies in daily clinical practice. In this review, the current data regarding the intrinsic subtypes and the associated clinical implications as well as the methodology of molecular profiling and possible use of immunohistochemistry in identifying intrinsic subtypes are discussed.

*These authors contributed equally to this work.

\author{
Schlüsselwörter \\ Mammakarzinom, invasives - Molekulare Subtypen . \\ Luminaler Typ · Basalzell-Typ · HER2
}

\section{Zusammenfassung}

In den letzten 10 Jahren hat das Verfahren der molekularen Charakterisierung durch die Schaffung einer neuen, auf der Expression von sogenannten «intrinsischen Genen" basierenden Taxonomie unser Verständnis von invasiven Mammakarzinomen grundlegend verändert. Durch hierarchische Cluster-Analysen an mittels Microarrays bestimmten Genexpressionsprofilen konnten distinkte Subgruppen des Mammakarzinoms definiert werden (luminaler Typ A/B, HER2-angereicherter Typ, Basalzell-Typ). Seit der bahnbrechenden Arbeit durch Perou et al. wurde das Konzept der intrinsischen Subtypen des Mammakarzinoms von mehreren Arbeitsgruppen bestätigt und erweitert. Weitere Studien zeigten wesentliche Unterschiede zwischen den intrinsischen Subgruppen bezüglich des klinischen Verlaufs und des Ansprechens auf Chemotherapie. Die neue, auf Genexpression basierende Taxonomie der invasiven Mammakarzinome wurde von der Wissenschaftsgemeinde begeistert angenommen und als Durchbruch auf dem Weg zur individualisierten Therapie gefeiert. Dennoch ist eine Validierung der auf Gensignaturen basierenden Untersuchungen in prospektiven Untersuchungen erforderlich, bevor diese Technologien im klinischen Alltag eingesetzt werden können. Diese Übersichtsarbeit befasst sich mit den intrinsischen Subtypen des invasiven Mammakarzinoms, den hiermit assoziierten klinischen Implikationen wie auch mit der Methodik der molekularen Charakterisierung und der Frage, ob die intrinsischen Subtypen auch mittels Immunhistochemie identifiziert werden können.

\section{KARGER \\ Fax +497614520714 \\ Information@Karger.de}

www.karger.com
(C) 2011 S. Karger GmbH, Freiburg

$1661-3791 / 11 / 0064-0258 \$ 38.00 / 0$

Accessible online at:

www.karger.com/brc
Prof. Dr. Arndt Hartmann

Pathologisches Institut

Universitätsklinikum Erlangen

Krankenhausstr. 8-10, 91054 Erlangen, Germany

Tel. +49 9131 85-22286, Fax -24745

Arndt.Hartmann@uk-erlangen.de 


\section{Introduction}

Invasive breast carcinoma is the most common cancer of women and has been categorized by histomorphological criteria into invasive ductal carcinoma (IDC), invasive lobular carcinoma (ILC), and other less common subtypes [1]. In most institutes, a 3-tiered grading scheme regarding growth pattern, nuclear grade and proliferative activity is used to further subdivide these subtypes [2]. Additionally, immunohistochemical analysis of estrogen receptor (ER), progesterone receptor (PR) and HER2 expression is carried out to determine if patients qualify for adjuvant therapy.

In recent years, DNA microarrays have been used to classify invasive breast carcinomas independently of histomorphological and immunohistochemical criteria. DNA microarrays represent a technology in which RNA is extracted from a tumor sample, transcribed into cDNA or cRNA and hybridized to microarray spots coated with DNA/RNA sequences representing distinct genes. With the aid of fluorescence labeling, the gene expression levels are determined in relation to a normal reference. With the advent of the DNA microarray technique, the determination of the expression levels of thousands of genes in one single tumor specimen has become possible [3].

\section{Discovery of Intrinsic Subtypes in Breast Cancer: The Seminal Work}

In their seminal work, Perou et al. [4] employed DNA microarrays for the investigation of the molecular profile of a collective of 65 surgical breast tumor specimens from 42 individual patients. A central concept of this study was that tumors could be characterized by the up- or down-regulation of special sets of genes, so-called 'intrinsic genes'. Intrinsic genes were defined as genes with significantly greater variation in expression between different tumors than between paired samples from the same tumor. On the basis of this algorithm, 496 gene probes representing an 'intrinsic gene list' were selected from an early microarray encompassing 8102 genes.

Numerous clusters representing genes associated with different breast cell types/functions were discovered. With the aid of hierarchical clustering analyses, 4 distinct molecular subgroups of invasive breast cancer were described: ER+/ luminal-like, basal-like, HER2 enriched and normal breastlike. By defining these so-called 'intrinsic' subtypes, the groundwork for a new molecular taxonomy was laid [4]. Of note, it is highly probable that the normal breast-like subtype is an artifact caused by sampling errors. This point will be discussed further in the section 'Critique of Methodology'. Another important piece of information derived from the experiment by Perou et al. is that the group of ER-negative breast cancers is made up of at least two biologically distinct subtypes of tumors (basal-like, HER2 enriched), which are now understood as distinct diseases with different treatment options.

\section{Molecular Subtypes, Mammary Development and Breast Cancer Evolution}

Perou et al. [4] suggested that the intrinsic subtypes might reflect the different molecular features of mammary epithelial biology. This hypothesis was taken further by Prat and Perou [5] who suggested that the majority of invasive breast cancers could be assigned to different developmental points of the mammary epithelium. However, detailed analyses of gene mutation profiles amongst intrinsic subtypes revealed distinct gene mutation patterns for the different intrinsic subtypes, with a high index of p53 mutations in basal-like carcinomas [6-8]. These findings suggest that in breast cancer the molecular subtype of carcinoma might either be determined by the cell of origin or different genomic alterations, or possibly a combination of both.

\section{Luminal Intrinsic Subtype}

The defining molecular feature of luminal-type breast cancer is the expression of the ER [4]. Luminal-type breast cancer carries the best prognosis of all intrinsic subtypes [9] and responds to endocrine therapy [3]. Interestingly, invasive lobular breast cancer (ILC) overwhelmingly is classified as luminal type $[10,11]$. Generally, ILC and low-grade IDC are subsumed as low-grade breast neoplasia family [12]. Molecular profiling seems to corroborate this concept. While basal-like and HER2-enriched breast cancers often respond well to neoadjuvant chemotherapy, the luminal subtypes show only limited chemosensitivity [13,14]. Sorlie et al. [9] were the first to suggest a subdivision of luminal-type carcinoma into at least 2 distinct subgroups with characteristic molecular profiles and different prognoses, namely luminal type A breast cancer (fig. 1) and luminal type B cancer (fig. 2). The major difference between luminal $\mathrm{A}$ and luminal B breast cancers is the degree of proliferation and the HER2 expression signature, which is more pronounced in luminal B-type breast cancers $[15,16]$. The distinction between luminal A and B carcinomas is of high clinical interest as luminal A-type breast carcinomas seem to be at a lower risk for relapse $[13,17]$ and luminal B-type breast carcinoma generally carries a worse prognosis but responds only slightly better to chemotherapy than luminal A-type carcinoma [18]. However, proliferation in $\mathrm{ER}+$ carcinomas is a continuum, which makes a separation of luminal subgroups on the basis of proliferation - be it on an immunohistochemical level or on a molecular level - arbitrary and defining a cut-off difficult $[13,19,20]$.

\section{Basal-Like Intrinsic Subtype}

The basal-like subtype of breast cancer (fig. 3) is characterized by the expression of cytokeratins, which are typically expressed in the basal cells of normal mammary gland epithelium, and by a very high expression of the proliferation cluster. It makes up approximately $15 \%$ of invasive breast cancers [21-23]. There is a striking prevalence of this mole- 

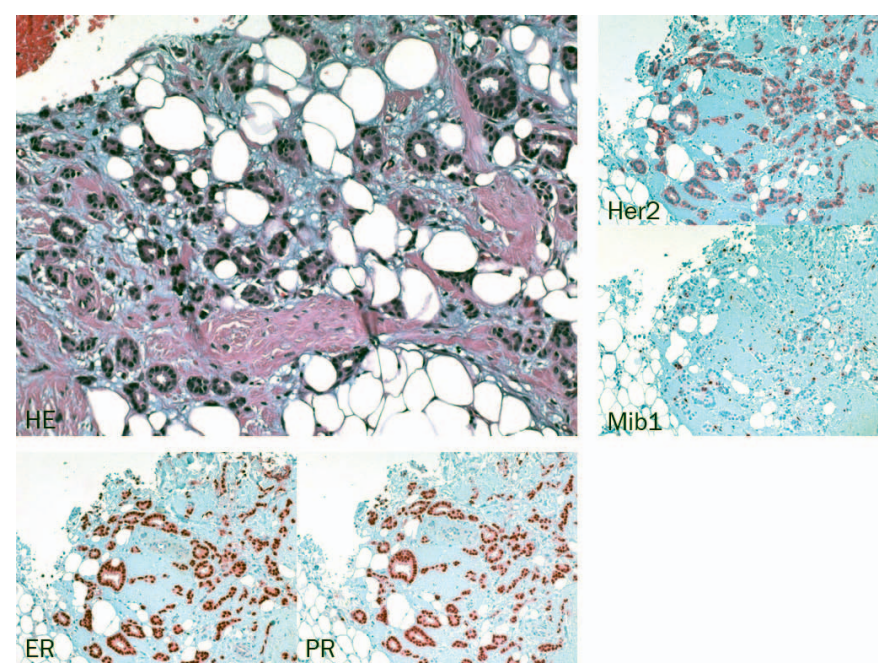

Fig. 1. Example of luminal A-type carcinoma: Well differentiated IDC (grade 1) with nuclear ER and PR expression in over $90 \%$ of tumor cells, HER2/neu negativity and a proliferative index of $<14 \%$ of tumor cells.
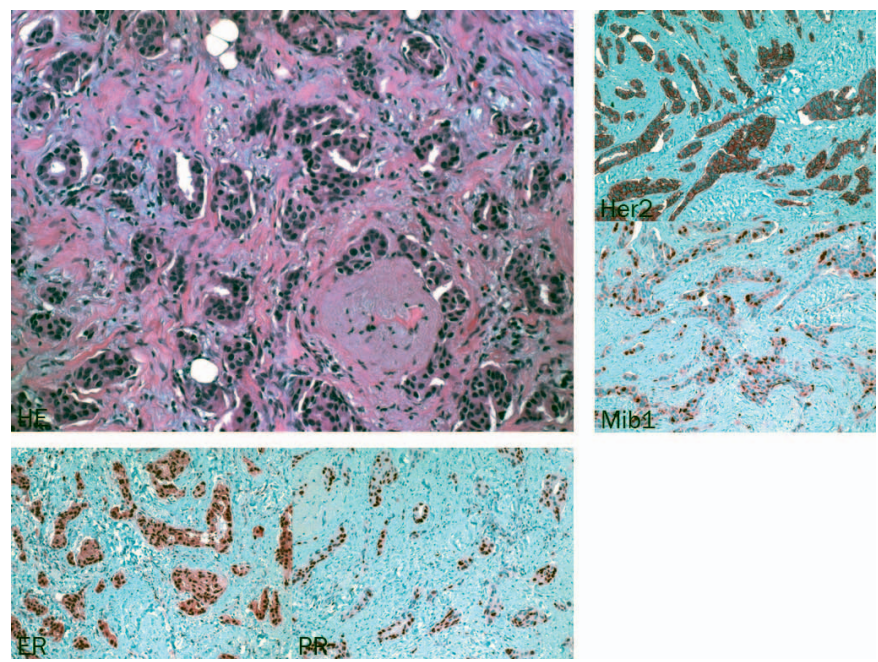

Fig. 2. Example of luminal B-type carcinoma: Moderately differentiated IDC (grade 2) with nuclear ER and PR expression in over $90 \%$ of tumor cells, HER $2 /$ neu expression and a proliferative index of $>14 \%$ of tumor cells.

cular subtype in premenopausal African-American women [22], which may partially explain the poor outcomes characteristic of this patient group. Interestingly, BRCA1 mutationassociated breast carcinomas as a group strongly resemble sporadic basal-like tumors and might be regarded as a special subgroup in this intrinsic subtype [4, 24, 25]. It has been shown that, among the intrinsic subtypes as determined by molecular profiling, the basal-like subtype and the HER2-enriched subtype treated with trastuzumab showed the highest response rates to neoadjuvant chemotherapy $[13,14]$.

\section{HER2-Enriched Intrinsic Subtype}

The HER2-enriched subtype of breast cancer (fig. 4) is defined by overexpression of the HER2/neu gene and a lack of expression of genes characteristic of the luminal subtypes. Up
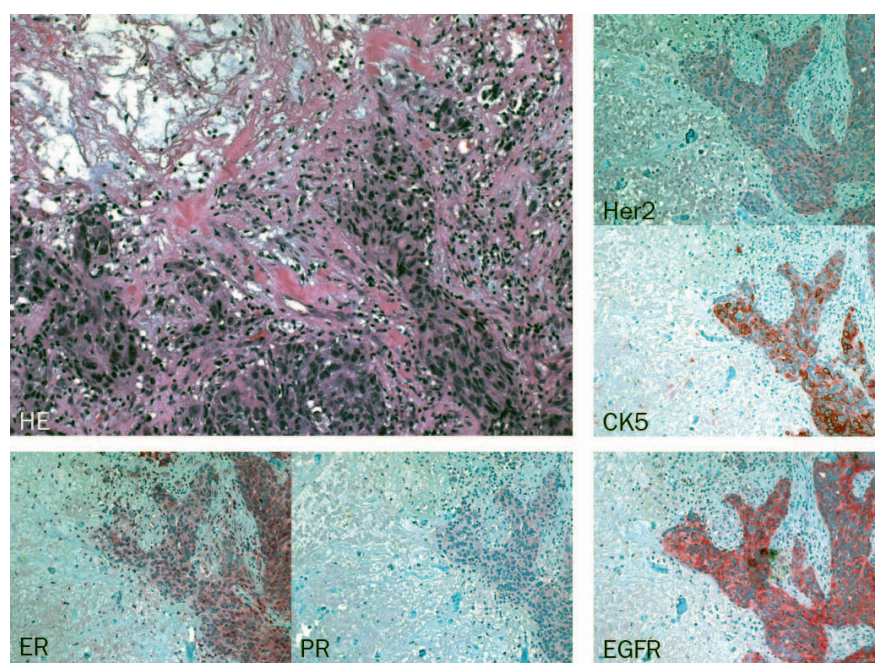

Fig. 3. Example of a basal-type carcinoma: Poorly differentiated invasive carcinoma with negativity for ER and PR and negativity for HER2/neu and expression of CK5 and EGFR.

to $25 \%$ of breast cancers are HER 2 positive as defined by immunohistochemistry and fluorescence in situ hybridization/ chromogenic in situ hybridization (FISH/CISH) [30]. It is intriguing that not all breast cancers defined as HER2 positive by immunohistochemistry are classified as HER2 enriched by molecular profiling. At the same time, not all intrinsic HER2 enriched tumors are diagnosed as HER2 amplified by immunohistochemistry or in situ hybridization [13,31,32]. Studies are needed to ascertain whether the molecular subtype HER2 enriched may profit from trastuzumab therapy in cases when HER2 amplification cannot be proven with conventional methods. Clinical experience demonstrates clearly that the collective of HER2-positive patients as defined by immunohistochemistry is a heterogeneous group, in particular regarding the response to HER2 blockers. It is well known that a significant number of patients with HER2-positive breast cancers possess a primary trastuzumab resistance or develop a secondary resistance to trastuzumab within 1 year [33]. Furthermore, it has been suggested that some patients with HER2-positive breast cancer might in fact even suffer a prognostic disadvantage from chemotherapy and trastuzumab therapy [34]. As of now, it is unclear whether the molecular subtyping with definition of the HER2-enriched intrinsic subtype performs better than immunohistochemistry or FISH/ CISH in the clinical context. Extensive studies will be needed to reliably identify the patients who will profit from a HER2targeting therapy, and hopes are high that molecular profiling will provide the solution of this therapeutical riddle.

\section{Potential New Intrinsic Subtypes: Claudin-Low Subtype and Apocrine Subtype}

Current data indicate that additional molecular subtypes will need to be incorporated into the molecular profiling system in order to render the biological picture more complete. 


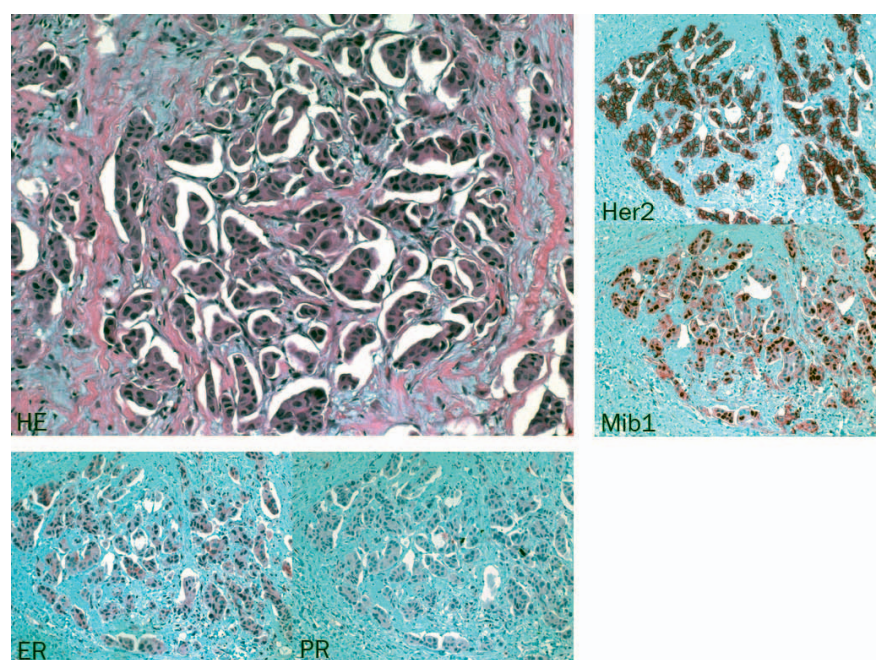

Fig. 4. Example of HER2/neu-enriched carcinoma: Poorly differentiated invasive micropapillary carcinoma with ER and PR negativity, strong membraneous expression of HER $2 /$ neu in $>30 \%$ of tumor cells and a proliferative index of $>14 \%$ of tumor cells.

Currently, the molecular subtype 'claudin-low' is moving into the center of the molecular researchers' attention. Neve et al. [26] reported a specific subtype in breast cancer cell lines that showed stem cell properties and was named 'basal B' subtype. The claudin-low subtype is characterized by a low expression of genes involved in tight junctions and cell-cell adhesion [27, 28]. Tumors of the claudin-low subtype resemble the basal-like subtype insofar as they show negativity for ER, PR and HER2. However, claudin-low tumors lack classical basal-like markers like cytokeratins 5/6 (CK5/6) and epidermal growth factor receptor (EGFR). According to Prat et al. [28], the claudin-low subtype represents $12-14 \%$ of the triple-negative carcinomas. As of now, data are lacking regarding the clinical implications of this new subtype. It is furthermore unclear whether the claudin-low subtype should be regarded as a distinct molecular and clinical subtype or rather as a component of the basal-like intrinsic subtype.

Another distinct molecular subgroup of breast tumors is characterized by ER negativity and androgen receptor (AR) positivity as well as by an apocrine morphology. The authors contend that tumors of the apocrine subtype may make up a substantial part of ER- tumors outside the basal subtype [29].

\section{Can Intrinsic Molecular Subtypes Be Reliably Identified by Immunohistochemistry or Even Histomorphology?}

Molecular profiling of cancer represents a time-consuming and expensive method and requires unfixed tumor tissue snap-frozen under standardized conditions immediately after surgery. Therefore, a question of great clinical relevance is whether the intrinsic subtypes can be reliably identified by histomorphology alone or through a standard immunohistochemistry panel.

Histomorphological criteria can provide useful clues to the diagnosis of the different molecular subtypes, e.g. luminal tumors usually show a good or moderate differentiation with tubule formation whereas basal-like carcinomas reveal poor differentiation with central necrosis and prominent lymphoid infiltrates. However, the discriminative power of histomorphology is very limited regarding intrinsic subtypes.

Regarding immunohistochemistry, different study groups have tried to emulate molecular subtyping using a standard immunohistochemistry surrogate panel encompassing ER, PR, HER2/neu and Ki67. Generally, the luminal subtype can be identified by immunohistochemical expression of the ER or the PR. As described above, luminal B carcinomas are characterized by additional HER2 expression and/or higher proliferation. Cheang et al. [15] have shown that the differentiation between luminal A and B tumors with a sensitivity of $77 \%$ and a specificity of $78 \%$ is possible using a Ki67 cut-off of $14 \%$. Recent studies have demonstrated that the combination of ER, HER2 and PR negativity and EGFR and CK5/6 positivity accurately identifies basal-like tumors from gene microarray data with $100 \%$ specificity and $76 \%$ sensitivity [23]. However, it has been shown that $9 \%$ of immunohistochemically triple-negative tumors were assigned to the HER2enriched subtype on a molecular level, whereas $5 \%$ and $6 \%$ showed a molecular pattern corresponding to luminal A and B, respectively [28]. This heterogeneity at the molecular level of tumors with a similar immunohistochemical profile was corroborated by other studies, which showed that virtually all intrinsic subtypes are represented in the different clinicopathological breast carcinoma categories $[13,35]$. This data suggests that the intrinsic subtypes are closely, but not fully and accurately represented by the standard immunohistochemical markers used in clinical practice today.

\section{Does Genetic Profiling Provide Additional Prognostic and Predictive Information beyond Standard Clinico-Pathological Parameters?}

The vast individualized data set generated by the molecular profiling of breast carcinoma has very soon led to the question whether the knowledge of the molecular profile of individual breast carcinomas also conveys significant prognostic and predictive information.

The advent of gene profiling has given a significant boost to the efforts of pinpointing those patients with ER+ breast carcinoma who will - with high probability - profit from adjuvant chemotherapy. At the same time, it is of major medical and financial interest to identify patients with a low risk of recurrence who could be spared the toxicity of chemotherapy. To this end, several working groups have devised molecular 
signature-based tests to better judge the risk of recurrence of ER-positive, lymph node-negative breast carcinomas. Amongst these tests, the most well known are the 70-gene good versus poor outcome model ('Mammaprint'; [36]), the 'wound response model' [37, 38], the recurrence score model ('OncotypeDX'; [39]), the intrinsic subtype model [4, 9, 24, 40] and the two gene ratio model [41]. Skepticism was induced by the fact that, although these tests were designed to be applied to the same clinical problem, only a small gene overlap exists between these tests [42]. However, when tested against the same data set, all tests but one (the two gene ratio model) showed similar prognostic values [17].

It has been argued that only high-throughput technologies are able to fully capture the biological diversity of breast carcinoma. In this context it needs to be mentioned that the proliferation (signature) is the mainstay in all classifiers to divide $\mathrm{ER}+$, lymph node-negative tumors into subgroups with different prognosis [43]. In particular, OncotypeDX relies heavily on proliferation-related genes [20]. This raises the question whether immunohistochemical or even histomorphological parameters might not be equally efficient as surrogates for prognosis and prediction instead of costly molecular assays. However, until today, results of prospective randomized studies addressing the question whether better prognostic or predictive information can be achieved using molecular profiling in comparison to the classical clinico-pathological data sets are lacking. Ongoing prospective studies like the Mindact study will hopefully clarify to which extent molecular profiling provides additional prognostic and predictive information.

\section{Molecular Profiling - a Critique of Methodology}

Molecular profiling has been enthusiastically received as an exciting new technology by the scientific community. However, there were also some calls for caution which criticized the over-enthusiastic and uncritical embracing of a new method still lacking rigorous validation [44, 45]. First of all, the new molecular taxonomy was based on findings derived from different microarray platforms. To address the question of reproducibility of microarray technology, the US Food and Drug Administration (FDA) instigated the Microarray Quality Control (MAQC) project. The data collected in this extensive study showed that microarray measurements are highly reproducible within and across different microarray platforms. As a consequence, the FDA judged the microarray technology sufficiently reliable for clinical and regulatory purposes [46]. However, it needs to be pointed out that different profiling gene sets cannot be transferred from one microarray platform to another without extensive modification. As a consequence, the results of different microarray platforms cannot be directly compared. Another point of critique concerns the samples used for microarray technologies. As the tissue samples are not microdissected before analysis, the gene profiles represent not only the tumor cells but also the peritumoral reaction and the host tissue. It seems probable that the subtype of normal-like breast carcinoma is an artifact of gene expression profiling, caused by the analysis of samples with a high content of normal breast epithelial cells and stromal cells $[13,32]$. Furthermore, in the case of microinvasive carcinoma with extensive DCIS, there is no safe way of guaranteeing that the invasive carcinoma and not the in situ component are analyzed.

Beyond the level of methodology, the rather small sample sizes upon which the groundbreaking works of Perou and Sorlie were based were regarded with some uneasiness. Indeed, in his seminal work describing 'molecular portraits of human breast tumors', Perou analyzed a set of 65 surgical specimens derived from 42 different individuals [4]. In the following 2 publications by the Stanford group that further outlined the concept of molecular profiling of breast carcinoma, Sorlie et al. based their analyses on 78 and 115 breast carcinomas, respectively $[9,24]$. Considering that in these studies a whole new molecular profile-based taxonomy of breast carcinomas was developed, a greater sample size would have validated the new concept with greater statistical power.

As molecular profiling is often hailed as a largely unbiased analysis tool that allows scientists to avoid the subjectivity of immunohistochemistry and histopathological grading, it is often forgotten that the hierarchical clustering method, far from being a completely automated analysis, is a method that requires the input of a human observer for the final interpretation of the data. In a test encompassing the 5 major intrinsic gene lists, Mackay et al. [47] demonstrated that none of the classification systems produced almost perfect interobserver agreement. The best interobserver agreement was documented for basal-type and HER2-enriched breast carcinomas, whereas poor interobserver agreement was found for luminaltype breast carcinomas.

It is also important to bear in mind that the analyzing tool of hierarchical clustering can only be applied retrospectively, to adequately sized collectives. The classical microarray-based hierarchical clustering method is therefore not suitable for assigning intrinsic subtypes to particular samples as the dendrogram changes with each additionally included sample. To circumvent this particular problem, single sample predictors (SSPs) have been devised [13, 24, 40]. SSPs are based on the median expression patterns of the different intrinsic subtypes (i.e. centroids). The SSP allows for any given sample to be assigned to the intrinsic subtype most similar in its molecular profile. However, the reliability of SSPs has been discussed controversially. While some groups have reported reliable and reproducible intrinsic subgroup assignments through SSPs [40], others have questioned the validity of this method and claimed that only basal-like breast carcinomas were safely identified by this method [32]. Further studies are needed to ascertain whether SSPs represent a valid method for molecular subtyping. 
It must be noted that, while the technique of RNA-based molecular subtyping allows fascinating insights into the molecular properties of breast cancer, it is not (yet) a very good tool for assessing individual samples.

Despite the scientific and medial hype, we are therefore not yet at a point where this new technology has a relevant impact on day-to-day clinical practice.

\section{Conclusions}

The criticism inherent in the stringent validation of molecular profiling should not be misinterpreted as a rejection of an exciting new technology. Gene expression profiling carries an enormous potential and has taken us some way towards individualized therapy. The massive potential of this powerful high-throughput technology which allows investigators to better capture the molecular diversity of cancer cannot be overestimated, especially as the high-throughput technologies are continually being improved and expanded. It is to be expected that newer methods analyzing additional epigenetic factors such as non-coding RNAs and alternative splicing will complement and enrich molecular profiling in the future. Highthroughput technologies have opened the way to the acquisition of unprecedented amounts of data regarding individual tumors. As our technical prowess in molecular profiling in- creases, so will our understanding of breast cancer biology. However, the uncritical acceptance of new technologies may generate massive amounts of insufficiently validated data. In order to stay on top of this data flood, it is absolutely necessary to rigorously enforce standardization and validation of the new technologies. Furthermore, molecular profiling should be regarded as a component of the whole clinico-pathological picture and not be aggressively marketed as a superior substitute to the diagnostic, prognostic and predictive methods currently in use. Rather than furthering the cause of molecular profiling, the hybris of calling pathology unsophisticated and subjective [48], together with the rather spectacular claim that microarrays will be the key to curing all human disease until 2050 [49], serve as a provocation not only to surgical pathologists. Retaliation has occurred in the form of growing criticism, cumulating in one expert in biomarkers claiming that it is statistically and mathematically possible to prove that any given gene affects survival 'even if it does not' [44]. In the interest of science and patient care alike it is time to take the competitive edge out of the discussion regarding molecular profiling.

\section{Disclosure Statement}

The authors declare that there is no conflict of interest.

\section{References}

1 Ellis IO, Schnitt SJ, Sastre-Garau X, Bussolati G, Tavassoli FA, Eusebi V, Peterse JL, Mukai K, Tabar L, Jacquemier J, Cornelisse CJ, Sasco AJ, Kaaks R, Pisani P, Goldgar DE, Devilee P, Cleton-Jansen MJ, Borresen-Dale AL, van't Veer L, Sapino A: Invasive breast carcinoma; in Tavassoli FA, Devilee P (eds): Tumours of the Breast and Female Genital Organs. Lyon, IARC Press, 2003, pp 13-59.

2 Elston CW, Ellis IO: Pathological prognostic factors in breast cancer. I. The value of histological grade in breast cancer: Experience from a large study with long-term follow-up. Histopathology 1991;19:403-410.

3 Peppercorn J, Perou CM, Carey LA: Molecular subtypes in breast cancer evaluation and management: Divide and conquer. Cancer Invest 2008;26:1-10.

4 Perou CM, Sorlie T, Eisen MB, van de Rijn M, Jeffrey SS, Rees CA, Pollack JR, Ross DT, Johnsen H, Akslen LA, Fluge O, Pergamenschikov A, Williams C, Zhu SX, Lonning PE, Borresen-Dale AL, Brown PO, Botstein D: Molecular portraits of human breast tumours. Nature 2000;406:747-752.

5 Prat A, Perou CM: Mammary development meets cancer genomics. Nat Med 2009;15:842-844.

6 Hollestelle A, Nagel JH, Smid M, Lam S, Elstrodt F, Wasielewski M, Ng SS, French PJ, Peeters JK, Rozendaal MJ, Riaz M, Koopman DG, Ten Hagen TL, de Leeuw BH, Zwarthoff EC, Teunisse A, van der Spek PJ, Klijn JG, Dinjens WN, Ethier SP, Clevers H, Jochemsen AG, den Bakker MA, Foekens JA, Martens JW,
Schutte M: Distinct gene mutation profiles among luminal-type and basal-type breast cancer cell lines. Breast Cancer Res Treat 2010;121:53-64.

$7 \mathrm{Hu}$ X, Stern HM, Ge L, O'Brien C, Haydu L, Honchell CD, Haverty PM, Peters BA, Wu TD, Amler LC, Chant J, Stokoe D, Lackner MR, Cavet G: Genetic alterations and oncogenic pathways associated with breast cancer subtypes. Mol Cancer Res 2009;7:511-522.

8 Langerod A, Zhao H, Borgan O, Nesland JM, Bukholm IR, Ikdahl T, Karesen R, Borresen-Dale AL, Jeffrey SS: Tp53 mutation status and gene expression profiles are powerful prognostic markers of breast cancer. Breast Cancer Res 2007;9:R30.

7 Sorlie T, Perou CM, Tibshirani R, Aas T, Geisler S, Johnsen H, Hastie T, Eisen MB, van de Rijn M, Jeffrey SS, Thorsen T, Quist H, Matese JC, Brown PO, Botstein D, Eystein Lonning P, Borresen-Dale AL: Gene expression patterns of breast carcinomas distinguish tumor subclasses with clinical implications. Proc Natl Acad Sci USA 2001;98:10869-10874.

10 Weigelt B, Geyer FC, Natrajan R, LopezGarcia MA, Ahmad AS, Savage K, Kreike B, Reis-Filho JS: The molecular underpinning of lobular histological growth pattern: A genomewide transcriptomic analysis of invasive lobular carcinomas and grade- and molecular subtypematched invasive ductal carcinomas of no special type. J Pathol 2010;220:45-57.

11 Weigelt B, Horlings HM, Kreike B, Hayes MM, Hauptmann M, Wessels LF, de Jong D, Van de Vijver MJ, Van't Veer LJ, Peterse JL: Refinement of breast cancer classification by molecular char- acterization of histological special types. J Pathol 2008;216:141-150.

12 Abdel-Fatah TM, Powe DG, Hodi Z, Reis-Filho JS, Lee AH, Ellis IO: Morphologic and molecular evolutionary pathways of low nuclear grade invasive breast cancers and their putative precursor lesions: Further evidence to support the concept of low nuclear grade breast neoplasia family. Am J Surg Pathol 2008;32:513-523.

13 Parker JS, Mullins M, Cheang MC, Leung S, Voduc D, Vickery T, Davies S, Fauron C, He X, Hu Z, Quackenbush JF, Stijleman IJ, Palazzo J, Marron JS, Nobel AB, Mardis E, Nielsen TO, Ellis MJ, Perou CM, Bernard PS: Supervised risk predictor of breast cancer based on intrinsic subtypes. J Clin Oncol 2009;27:1160-1167.

14 Rouzier R, Perou CM, Symmans WF, Ibrahim N, Cristofanilli M, Anderson K, Hess KR, Stec J, Ayers M, Wagner P, Morandi P, Fan C, Rabiul I, Ross JS, Hortobagyi GN, Pusztai L: Breast cancer molecular subtypes respond differently to preoperative chemotherapy. Clin Cancer Res 2005;11:5678-5685.

15 Cheang MC, Chia SK, Voduc D, Gao D, Leung S, Snider J, Watson M, Davies S, Bernard PS, Parker JS, Perou CM, Ellis MJ, Nielsen TO: Ki67 index, HER2 status, and prognosis of patients with luminal B breast cancer. J Natl Cancer Inst 2009;101:736-750.

16 Nielsen TO, Parker JS, Leung S, Voduc D, Ebbert M, Vickery T, Davies SR, Snider J, Stijleman IJ, Reed J, Cheang MC, Mardis ER, Perou CM, Bernard PS, Ellis MJ: A comparison of PAM50 intrinsic subtyping with immuno- 
histochemistry and clinical prognostic factors in tamoxifen-treated estrogen receptor-positive breast cancer. Clin Cancer Res 2010;16:5222-5232.

17 Fan C, Oh DS, Wessels L, Weigelt B, Nuyten DS, Nobel AB, van't Veer LJ, Perou CM: Concordance among gene-expression-based predictors for breast cancer. N Engl J Med 2006;355:560-569.

18 Carey LA, Dees EC, Sawyer L, Gatti L, Moore DT, Collichio F, Ollila DW, Sartor CI, Graham ML, Perou CM: The triple negative paradox: Primary tumor chemosensitivity of breast cancer subtypes. Clin Cancer Res 2007;13:2329-2334.

19 Desmedt C, Haibe-Kains B, Wirapati P, Buyse M, Larsimont D, Bontempi G, Delorenzi M, Piccart M, Sotiriou C: Biological processes associated with breast cancer clinical outcome depend on the molecular subtypes. Clin Cancer Res 2008;14:5158-5165.

20 Wirapati P, Sotiriou C, Kunkel S, Farmer P, Pradervand S, Haibe-Kains B, Desmedt C, Ignatiadis M, Sengstag T, Schutz F, Goldstein DR, Piccart M, Delorenzi M: Meta-analysis of gene expression profiles in breast cancer: Toward a unified understanding of breast cancer subtyping and prognosis signatures. Breast Cancer Res 2008;10:R65.

21 Abd El-Rehim DM, Pinder SE, Paish CE, Bell J, Blamey RW, Robertson JF, Nicholson RI, Ellis IO: Expression of luminal and basal cytokeratins in human breast carcinoma. J Pathol 2004;203:661-671.

22 Carey LA, Perou CM, Livasy CA, Dressler LG, Cowan D, Conway K, Karaca G, Troester MA, Tse CK, Edmiston S, Deming SL, Geradts J, Cheang MC, Nielsen TO, Moorman PG, Earp HS, Millikan RC: Race, breast cancer subtypes, and survival in the Carolina Breast Cancer Study. JAMA 2006;295:2492-2502.

23 Nielsen TO, Hsu FD, Jensen K, Cheang M, Karaca G, Hu Z, Hernandez-Boussard T, Livasy C, Cowan D, Dressler L, Akslen LA, Ragaz J, Gown AM, Gilks CB, van de Rijn M, Perou CM: Immunohistochemical and clinical characterization of the basal-like subtype of invasive breast carcinoma. Clin Cancer Res 2004;10:5367-5374.

24 Sorlie T, Tibshirani R, Parker J, Hastie T, Marron JS, Nobel A, Deng S, Johnsen H, Pesich R, Geisler S, Demeter J, Perou CM, Lonning PE, Brown PO, Borresen-Dale AL, Botstein D: Repeated observation of breast tumor subtypes in independent gene expression data sets. Proc Natl Acad Sci USA 2003;100:8418-8423.

-25 Turner N, Tutt A, Ashworth A: Hallmarks of 'BRCAness' in sporadic cancers. Nat Rev Cancer 2004;4:814-819.

26 Neve RM, Chin K, Fridlyand J, Yeh J, Baehner FL, Fevr T, Clark L, Bayani N, Coppe JP, Tong F, Speed T, Spellman PT, DeVries S, Lapuk A, Wang NJ, Kuo WL, Stilwell JL, Pinkel D, Albertson DG, Waldman FM, McCormick F, Dickson RB, Johnson MD, Lippman M, Ethier S, Gazdar A, Gray JW: A collection of breast cancer cell lines for the study of functionally distinct cancer subtypes. Cancer Cell 2006;10:515-527.

27 Herschkowitz JI, Simin K, Weigman VJ, Mikaelian I, Usary J, Hu Z, Rasmussen KE, Jones LP, Assefnia S, Chandrasekharan S, Backlund MG, Yin Y, Khramtsov AI, Bastein R, Quackenbush J, Glazer RI, Brown PH, Green JE, Kopelovich L, Furth PA, Palazzo JP, Olopade OI, Bernard PS, Churchill GA, Van Dyke T, Perou CM: Identification of conserved gene expression features between murine mammary carcinoma models and human breast tumors. Genome Biol 2007;8:R76.
28 Prat A, Parker JS, Karginova O, Fan C, Livasy C, Herschkowitz JI, He X, Perou CM: Phenotypic and molecular characterization of the claudin-low intrinsic subtype of breast cancer. Breast Cancer Res 2010;12:R68

29 Farmer P, Bonnefoi H, Becette V, Tubiana-Hulin M, Fumoleau P, Larsimont D, Macgrogan G, Bergh J, Cameron D, Goldstein D, Duss S, Nicoulaz AL, Brisken C, Fiche M, Delorenzi M, Iggo R: Identification of molecular apocrine breast tumours by microarray analysis. Oncogene 2005;24:4660-4671.

30 Slamon DJ: Proto-oncogenes and human cancers. N Engl J Med 1987;317:955-957.

31 de Ronde JJ, Hannemann J, Halfwerk H, Mulder L, Straver ME, Vrancken Peeters MJ, Wesseling J, van de Vijver M, Wessels LF, Rodenhuis S: Concordance of clinical and molecular breast cancer subtyping in the context of preoperative chemotherapy response. Breast Cancer Res Treat 2010;119:119-126.

32 Weigelt B, Mackay A, A'Hern R, Natrajan R, Tan DS, Dowsett M, Ashworth A, Reis-Filho JS: Breast cancer molecular profiling with single sample predictors: A retrospective analysis. Lancet Oncol 2010;11:339-349.

33 Hubalek M, Brunner C, Mattha K, Marth C: Resistance to HER2-targeted therapy: Mechanisms of trastuzumab resistance and possible strategies to overcome unresponsiveness to treatment. Wien Med Wochenschr 2010;160:506-512.

34 Harris LN, You F, Schnitt SJ, Witkiewicz A, Lu X, Sgroi D, Ryan PD, Come SE, Burstein HJ, Lesnikoski BA, Kamma M, Friedman PN, Gelman R, Iglehart JD, Winer EP: Predictors of resistance to preoperative trastuzumab and vinorelbine for HER2-positive early breast cancer. Clin Cancer Res 2007;13:1198-1207.

35 Prat A, Perou CM: Deconstructing the molecular portraits of breast cancer. Mol Oncol 2010;5:5-23.

36 van't Veer LJ, Dai H, van de Vijver MJ, He YD, Hart AA, Mao M, Peterse HL, van der Kooy K, Marton MJ, Witteveen AT, Schreiber GJ, Kerkhoven RM, Roberts C, Linsley PS, Bernards R, Friend SH: Gene expression profiling predicts clinical outcome of breast cancer. Nature 2002;415:530-536.

37 Chang HY, Nuyten DS, Sneddon JB, Hastie T, Tibshirani R, Sorlie T, Dai H, He YD, van't Veer LJ, Bartelink H, van de Rijn M, Brown PO, van de Vijver MJ: Robustness, scalability, and integration of a wound-response gene expression signature in predicting breast cancer survival. Proc Natl Acad Sci USA 2005;102:3738-3743.

38 Chang HY, Sneddon JB, Alizadeh AA, Sood R, West RB, Montgomery K, Chi JT, van de Rijn M, Botstein D, Brown PO: Gene expression signature of fibroblast serum response predicts human cancer progression: Similarities between tumors and wounds. PLoS Biol 2004;2:E7.

39 Paik S, Shak S, Tang G, Kim C, Baker J, Cronin M, Baehner FL, Walker MG, Watson D, Park T, Hiller W, Fisher ER, Wickerham DL, Bryant J, Wolmark N: A multigene assay to predict recurrence of tamoxifen-treated, node-negative breast cancer. N Engl J Med 2004;351:2817-2826.

$40 \mathrm{Hu}$ Z, Fan C, Oh DS, Marron JS, He X, Qaqish BF, Livasy C, Carey LA, Reynolds E, Dressler L, Nobel A, Parker J, Ewend MG, Sawyer LR, Wu J, Liu Y, Nanda R, Tretiakova M, Ruiz Orrico A, Dreher D, Palazzo JP, Perreard L, Nelson E, Mone M, Hansen H, Mullins M, Quackenbush JF, Ellis MJ, Olopade OI, Bernard PS, Perou CM: The molecular portraits of breast tumors are conserved across microarray platforms. BMC Genomics 2006;7:96.

$41 \mathrm{Ma}$ XJ, Wang Z, Ryan PD, Isakoff SJ, Barmettler A, Fuller A, Muir B, Mohapatra G, Salunga R, Tuggle JT, Tran Y, Tran D, Tassin A, Amon P, Wang W, Enright E, Stecker K, Estepa-Sabal E, Smith B, Younger J, Balis U, Michaelson J, Bhan A, Habin K, Baer TM, Brugge J, Haber DA, Erlander MG, Sgroi DC: A two-gene expression ratio predicts clinical outcome in breast cancer patients treated with tamoxifen. Cancer Cell 2004;5:607-616.

42 Dupuy A, Simon RM: Critical review of published microarray studies for cancer outcome and guidelines on statistical analysis and reporting. J Natl Cancer Inst 2007;99:147-157.

43 Sotiriou C, Wirapati P, Loi S, Harris A, Fox S, Smeds J, Nordgren H, Farmer P, Praz V, Haibe-Kains B, Desmedt C, Larsimont D, Cardoso F, Peterse H, Nuyten D, Buyse M, Van de Vijver MJ Bergh J, Piccart M, Delorenzi M: Gene expression profiling in breast cancer: Understanding the molecular basis of histologic grade to improve prognosis. J Natl Cancer Inst 2006;98:262-272.

44 Ioannidis JP: Microarrays and molecular research: Noise discovery? Lancet 2005;365:454-455.

45 Simon R, Radmacher MD, Dobbin K, McShane LM: Pitfalls in the use of DNA microarray data for diagnostic and prognostic classification. J Natl Cancer Inst 2003:95:14-18.

46 Shi L, Reid LH, Jones WD, Shippy R, Warrington JA, Baker SC, Collins PJ, de Longueville F, Kawasaki ES, Lee KY, Luo Y, Sun YA, Willey JC, Setterquist RA, Fischer GM, Tong W, Dragan YP, Dix DJ, Frueh FW, Goodsaid FM, Herman D, Jensen RV, Johnson CD, Lobenhofer EK, Puri RK, Schrf U, Thierry-Mieg J, Wang C, Wilson M, Wolber PK, Zhang L, Amur S, Bao W, Barbacioru CC, Lucas AB, Bertholet V, Boysen C, Bromley B Brown D, Brunner A, Canales R, Cao XM, Cebula TA, Chen JJ, Cheng J, Chu TM, Chudin E, Corson J, Corton JC, Croner LJ, Davies C, Davison TS, Delenstarr G, Deng X, Dorris D, Eklund AC, Fan XH, Fang H, Fulmer-Smentek S, Fuscoe JC, Gallagher K, Ge W, Guo L, Guo X, Hager J, Haje PK, Han J, Han T, Harbottle HC, Harris SC, Hatchwell E, Hauser CA, Hester S, Hong H, Hurban P, Jackson SA, Ji H, Knight CR, Kuo WP, LeClerc JE, Levy S, Li QZ, Liu C, Liu Y, Lombardi MJ, Ma Y, Magnuson SR, Maqsodi B, McDaniel T, Mei N, Myklebost O, Ning B, Novoradovskaya N, Orr MS, Osborn TW, Papallo A, Patterson TA, Perkins RG, Peters EH, Peterson R, Philips KL, Pine PS, Pusztai L, Qian F, Ren H, Rosen M, Rosenzweig BA, Samaha RR, Schena M, Schroth GP, Shchegrova S, Smith DD, Staedtler F, Su Z, Sun H, Szallasi Z, Tezak Z, Thierry-Mieg D, Thompson KL, Tikhonova I, Turpaz Y, Vallanat B, Van C, Walker SJ, Wang SJ, Wang Y, Wolfinger R, Wong A, Wu J, Xiao C, Xie Q, Xu J, Yang W, Zhong S, Zong Y, Slikker W Jr: The microarray quality control (MAQC) project shows inter- and intraplatform reproducibility of gene expression measurements. Nat Biotechnol 2006;24:1151-1161.

47 Mackay A, Weigelt B, Grigoriadis A, Kreike B, Natrajan R, A'Hern R, Tan DS, Dowsett M, Ashworth A, Reis-Filho JS: Microarray-based class discovery for molecular classification of breast cancer: Analysis of interobserver agreement. J Natl Cancer Inst 2010;103:662-673.

$48 \mathrm{He}$ YD, Friend SH: Microarrays - the 21st century divining rod? Nat Med 2001;7:658-659.

49 Schena M: Microarray Analysis. Hoboken, WileyLiss, 2003. 